\title{
Gender Myths and Feminist Fables: Repositioning Gender in Development Policy and Practice Workshop
}

\section{List of participants}

Nida Abu Awwad - Bir Zeit University, Palestine

Nandinee Bandyopadhyay - Independent

Consultant, India

Stephanie Barrientos - IDS, UK

Srilatha Batliwala - Harvard University, USA

Jo Beall - LSE, UK

Sylvia Chant - LSE, UK

Francis Cleaver - Bradford University, UK

Andrea Cornwall - IDS, UK

Deepa Dhanraj - D\&N Productions, India

Jo Doezema - IDS, UK

Diane Elson - University of Essex, UK

Rosalind Eyben - IDS, UK

Sue Fleming - DFID, Brazil

Nandita Gandhi - Akshara, India

Anne Marie Goetz - IDS, UK

Mercedes Gonzalez de la Rocha - CIESAS del

Occidente, Mexico

Margaret Greene - Population Action, USA

Elizabeth Harrison - University of Sussex, UK

Irene Hoel - NORAD, Norway

Shireen Huq - Narriphoko, Bangladesh

Cecile Jackson - UEA, UK

Islah Jad - Bir Zeit University/SOAS

Gerd Johnsson-Latham - Swedish Ministry for

Foreign Affairs

Susie Jolly - IDS, UK

Naila Kabeer - IDS, UK

Deniz Kandiyoti - SOAS, UK

Nazneen Kanji - IIED, UK

Melissa Leach - IDS, UK

Amina Mama - African Gender Institute,

University of Cape Town

Marjorie Mbilinyi - HakiElimu, Tanzania

Maxine Molyneux - ILAS, UK

Maitrayee Mukhopadhyay - KIT, The

Netherlands
Bridget O'Laughlin - ISS, The Netherlands Rekha Pappu - Anveshi, Hyderabad, India Ruth Pearson - University of Leeds, UK

Nitya Rao - UEA, UK

Lamia Rashid - Save the Children Fund,

Bangladesh

Hazel Reeves - BRIDGE, UK

Cecilia Sardenberg - Universidade Federal de

Bahia, Brazil

Charlie Sever - BRIDGE

Nandita Shah - Akshara, India

Ylva Sornam Nath - Sida, Sweden

Hilary Standing - IDS, UK

Ramya Subrahmanian - IDS, UK

Alison Todes - University of Natal, South Africa

Dzodzi Tsikata - University of Legon, Ghana

Susanne Wadstein - Sida, Sweden

Sarah White - Bath University, UK

Ann Whitehead - University of Sussex, UK

Everjoice Win - ActionAid, Zimbabwe

Prudence Woodford-Berger - Swedish Ministry

of Foreign Affairs

Sushila Zeitlyn - DFID, Bangladesh

\section{Workshop papers}

Keynote Lecture: Amina Mama: Unleashing Critical Capacities: Preliminary Reflections on Feminist Praxis in Selected African Contexts

Nandinee Bandyopadhyay: 'Streetwalkers Show the Way': Reframing the Debate on Trafficking from Shop Workers' Perspective

Srilatha Batliwala/Deepa Dhanraj: Where Gender Meets Resurgent Patriarchy - A Report on Gender Myth and Feminist Fables from the Indian Frontline

Jo Beall/Alison Todes: Headlines or Head-space? Challenging Gender Planning Orthodoxy in Areabased Urban Development 
Sylvia Chant: Dangerous Equations? How Femaleheaded Households Became the Poorest of the Poor: Causes, Consequences and Cautions

Frances Cleaver: Community Work, Gender and Social Capital

Jo Doezema: Sex Slaves and Discourse Masters: The Myth of Trafficking in Women

Rosalind Eyben: Why Aid Needs Women

Sue Fleming: Who are the Women we are Working With? A Practitioner's Tale on Power and Difference

Nandita Gandhi: Women Have Low Paid Unskilled Jobs so They are the Last to be Hired and the First to be Fired

Anne Marie Goetz: Political Cleaners: How Women are the New Anti-Corruption Force. Does the Evidence Wash?

Mercedes Gonzalez de la Rocha: The Construction of the Survival Myth

Cecile Jackson: Risk, Insurance and Gender: Some Slightly Contrarian Thoughts

Isla Jad: The NGO-isation of the Arab Women's Movements

Gerd Johnson-Latham: Female Poverty and Deprivation: Definitions, Extent and Causes

Susie Jolly: Southern Sexualities are all the Same

Deniz Kandiyoti: Political Fiction Meets Gender Myth:

Post-conflict Reconstruction, "Democratisation" and Women's Rights

Nazneen Kanji/Carin Vijfhuizen: Cracking the Cashew Nut Myths?: Women's Agency and Policy Discourse in the Cashew Sector in Mozambique

Melissa Leach: Earth Mother Myths and Other Ecofeminist Fables
Marjorie Mbilinyi: Globalisation Hurts Women More Than Men

Maxine Molyneux: Social Capital: A Post Transition Concept? Questions of Context and Gender from a Latin American Perspective

Maitrayee Mukhopadhyay: Mainstreaming Gender or "Streaming" Gender Away: Feminists Marooned in the Development Business

Bridget O'Laughlin: A Bigger Piece of a Very Small Pie: Intra-household Resource Allocation and Poverty Reduction in Africa

Rekha Pappu: Within the Edifice of Development: Education of Women in India

Nitya Rao: Only Women Can and Will Represent Women's Interests: The Case of Land Rights

Cecilia M.B. Sardenberg: Women? Translations, Resignifications, and Myths of "Gender" in Development Policy and Planning in Brazil

Nandita Shah: Paid Work Gives Women a Better Status and a Decision-making Role Within the Family/ Household

Hilary Standing: Institutionalising Gender at a Sectoral Level - What Does it Mean and Who Does it?

Dzodzi Tsikata: From Gender Mainstreaming to a Rights Based Approach: What is New and What Does it Mean for Gender Equality Policies?

Sarah White: The "Gender lens": A Racial Blinder?

Ann Whitehead: Women, Men and African Agriculture

Everjoice Win: Not Really Poor, Powerless and Pregnant: But Who Are These Women? Personal Reflections from Feminist Activism

Prudence Woodford-Berger: Gender Mainstreaming: What is it (About) and Should we Continue Doing it?

The Gender and Development In Brief Special Issue on 'Gender Myths', September 2004, brings together highlights from the Feminist Fables and Gender Myths conference in a six-page easy-to-read format. This is available free in English, French and Spanish, online at www.bridge.ids.ac.uk/ or can be ordered in email version or printed copy from:

BRIDGE, Institute of Development Studies, University of Sussex, Brighton BN1 9RE, United Kingdom

Tel: $+44(0) 1273606261$

Fax: $+44(0) 1273621202$

Email: bridge@ids.ac.uk 